\title{
A warmer and drier climate in the northern sagebrush biome does not promote cheatgrass invasion or change its response to fire
}

\author{
Christian D. Larson ${ }^{1} \cdot$ Erik A. Lehnhoff $^{2} \cdot$ Lisa J. Rew $^{1}$
}

Received: 20 January 2017 / Accepted: 29 September 2017 / Published online: 16 October 2017

(C) The Author(s) 2017. This article is an open access publication

\begin{abstract}
Dryland shrub communities have been degraded by a range of disturbances and now face additional stress from global climate change. The spring/summer growing season of the North American sagebrush biome is projected to become warmer and drier, which is expected to facilitate the expansion of the invasive annual grass Bromus tectorum (cheatgrass) and alter its response to fire in the northern extent of the biome. We tested these predictions with a factorial experiment with two levels of burning (spring burn and none) and three climate treatments (warming, warming + drying, and control) that was repeated over 3 years in a Montana sagebrush steppe. We expected the climate treatments to make $B$. tectorum more competitive with the native perennial grass community, especially Pseudoroegneria spicata, and alter its response to fire. Experimental warming and warming + drying reduced $B$. tectorum cover, biomass, and fecundity, but there was no response to fire except for
\end{abstract}

Communicated by Yu-Long Feng.

Electronic supplementary material The online version of this article (doi:10.1007/s00442-017-3976-3) contains supplementary material, which is available to authorized users.

Christian D. Larson

utah131@gmail.com

Erik A. Lehnhoff

lehnhoff@nmsu.edu

Lisa J. Rew

lrew@montana.edu

1 Weed and Invasive Plant Ecology and Management Group, Land Resources and Environmental Science Department, Montana State University, Bozeman, MT 59717, USA

2 Entomology, Plant Pathology and Weed Science, New Mexico State University, Las Cruces, NM 88003, USA fecundity, which increased; the native grass community was the most significant factor that affected B. tectorum metrics. The experimental climate treatments also negatively affected $P$. spicata, total native grass cover, and community biodiversity, while fire negatively affected total native grass cover, particularly when climate conditions were warmer and drier. Our short-term results indicate that without sufficient antecedent moisture and a significant disruption to the native perennial grass community, a change in climate to a warmer and drier spring/summer growing season in the northern sagebrush biome will not facilitate $B$. tectorum invasion or alter its response to fire.

Keywords Bromus tectorum . Climate change . Pseudoroegneria spicata $\cdot$ Fire-feedback $\cdot$ Sagebrush biome

\section{Introduction}

The sagebrush biome covers more than 43 million hectares and is one of the largest ecosystems in North America (Rowland et al. 2010). It provides productive rangelands (Rowland et al. 2010), acts as an important carbon sink (Gilmanov et al. 2006), and fosters biodiverse native communities that provide habitat for threatened species (Miller et al. 2011). This region has an extensive history of disturbance (grazing, fire, development) (Knapp 1996; Rowland et al. 2010), which continues today. Understanding the effects of these disturbances in a changing climate is important for maintaining ecosystem diversity and productivity. One of the most significant results of disturbance within this region has been its role in the spread of non-native invasive plant species, which negatively impact the region's biodiversity and productivity (Rowland et al. 2010). 
The non-native invasive plant species that has had the most negative impact and poses the greatest threat to sagebrush ecosystems is the winter annual grass Bromus tectorum (Suring et al. 2005). Bromus tectorum, accidently introduced in the 1880s, was widespread throughout western North America by the 1920s (Mack 1981), and is currently naturalized throughout much of North America (Morrow and Stahlman 1984). As a winter annual, B. tectorum can germinate in the fall, winter, or spring (Morrow and Stahlman 1984), which affords it a competitive edge over native seedlings (Morrow and Stahlman 1984). However, this early germination and its subsequent growth requires suitable climate conditions, most importantly ample winter/spring soil moisture availability (Bradford and Lauenroth 2006; Bradley et al. 2016).

Bromus tectorum's invasion has been closely tied with anthropogenic disturbance; grazing facilitated its dispersal and establishment, and a positive feedback with fire has led to its ecological dominance in some areas (Mack 1981; Knapp 1996; Taylor et al. 2014). This dominance has largely been constrained to the Great Basin, Columbia Plains, and Colorado Plateau regions (Mack 1981; Knapp 1996; Bradley 2009; Brummer et al. 2016; Downs et al. 2016). Research into the mechanisms behind this dominance and what has constrained it to these regions has demonstrated the importance of the dynamic between the native grass community, disturbance, and climate (Chambers et al. 2014a, b).

Ecosystem resilience is an ecosystem's capacity to regain fundamental structure, processes, and functioning after stresses or disturbances (Chambers et al. 2014a), while an ecosystem's resistance to invasion is a function of the attributes and ecological processes that limit an invading species (Chambers et al. 2014a). Robust, undisturbed native perennial grass communities are resistant to $B$. tectorum invasion and limit its dominance (Chambers et al. 2007; Brummer et al. 2016), while disturbance (especially fire and grazing) of these communities increases the risk of B. tectorum invasion (Mack 1981). This makes the resilience of native ecosystems to disturbance important for how resistant the community is to B. tectorum invasion (Chambers et al. 2014a). Temperature and precipitation regimes affect sagebrush ecosystem resilience to fire (Chambers et al. 2014a); warmer and drier ecosystems are less resilient to fire than cooler and wetter ecosystems (Chambers et al. 2007, 2014a, b). The lower resilience of warmer and drier ecosystems has made them more susceptible to $B$. tectorum invasion following disturbance (Chambers et al. 2007, 2014a, b; Taylor et al. 2014). Consistent with these studies, the combination of warm and dry summer climate conditions is a key factor defining $B$. tectorum invasiveness throughout the sagebrush biome (Bansal and Sheley 2016; Brummer et al. 2016). Similarly, areas where the B. tectorum-fire cycle has been found are warmer and receive less summer precipitation than those areas where $B$. tectorum has yet to demonstrate a positive feedback with fire (Taylor et al. 2014).

Climate models for the northern sagebrush biome project temperatures to increase by $2-4{ }^{\circ} \mathrm{C}$ by 2100 and, while there is a lot or variation in the model projections for precipitation, summer precipitation is projected to decrease (Mote and Salathé 2010; Pederson et al. 2010; Polley et al. 2013) and soils to become drier in the summer resulting in greater plant water stress (Bradley et al. 2016). These changes will potentially make ecosystems more climatically similar to the rest of the biome and, thus, less resilient to disturbance and resistant to $B$. tectorum invasion. Accordingly, given ample late winter/early spring soil moisture availability, climate envelope models have projected that as summer temperatures warm and spring/summer precipitation and soil moisture decrease there will be an expansion of both B. tectorum dominance and its positive feedback with fire at higher elevations and latitudes (Bradley 2009; Taylor et al. 2014; Bradley et al. 2016). Recent B. tectorum climate manipulation studies in Utah and southern Wyoming have demonstrated that experimentally increased temperatures positively affect $B$. tectorum (Zelikova et al. 2013; Compagnoni and Adler 2014a, b; Blumenthal et al. 2016), and B. tectorum has expanded along its high elevation range margin in Colorado (Bromberg et al. 2011). Similarly, experimentally reduced precipitation of an invaded Colorado mixed prairie positively affected $B$. tectorum seed production and cover (Prevéy and Seastedt 2015). While a study that employed a prescribed burn in the fall found the treatment to negatively affect overwinter B. tectorum seedling survival, it also demonstrated that burning increased $B$. tectorum biomass and fecundity (Chambers et al. 2007). Finally, both observational and experimental fire studies, with sites in the Great Basin and Columbia Basin regions, have found that ecosystem resilience to fire is lowest in warm and dry sites and greatest in cool and moist sites, resulting in greater B. tectorum invasion at the warm and dry sites after fire (Chambers et al. 2007, 2014b; Dodson and Root 2016), especially if the perennial grasses and forbs have been reduced.

Bromus tectorum is naturalized in Montana, however, in this relatively cold and wet northern region of the sagebrush biome there have not been any documented cases of $B$. tectorum dominating natural ecosystems by forming dense monocultures, nor any cases of the positive $B$. tectorum-fire cycle (Taylor et al. 2014). A change in climate may not only facilitate the spread of $B$. tectorum within this region but could also effect a change from its current subordinate community role to what has been referred to as a 'transformer', initiating a $B$. tectorum-fire cycle (Richardson et al. 2000; Hellmann et al. 2008; Taylor et al. 2014). At the time of this study, small-scale field experiments have addressed the possibility of a $B$. tectorum range shift by elevating temperatures (Zelikova et al. 2013; Compagnoni and Adler 2014a, 
b; Blumenthal et al. 2016) and altering precipitation patterns (Prevéy and Seastedt 2015). However, no studies have experimentally increased the temperature and decreased the precipitation of $B$. tectorum communities. Likewise, no studies have addressed the potential for climate change to induce a $B$. tectorum community role change by altering the climate factors of recently burned $B$. tectorum communities, particularly at a northerly latitude where it is limited by cold and relatively dry winters and wet summers.

The goal of this study was to assess the responses of $B$. tectorum, Pseudoroegneria spicata, and the native plant community in a northern sagebrush steppe site to experimentally increased growing season temperatures and decreased growing season precipitation, in addition to a spring burn. The questions of our study were: (1) How will $B$. tectorum's and $P$. spicata's abundance (cover and biomass) and fecundity, as well as native plant community cover, respond to experimental growing season warming? (2) How will these same response variables respond to experimental growing season warming + drying? We expected to find a negative relationship between the native grass community and $B$. tectorum. Thus, our next question was: (3) How will the interactions between $B$. tectorum and P. spicata, and between $B$. tectorum and the native grass community be affected by the two climate treatments? Similarly, (4) how will B. tectorum's impact on community biodiversity be altered by the climate treatments? Our final question: (5) What effect will a spring prescribed burn have on the aforementioned B. tectorum, $P$. spicata, and native community response variables under experimentally warmed and dried conditions?

\section{Methods}

\section{Study site}

The study site was a sagebrush steppe rangeland located $56 \mathrm{~km}$ west of Bozeman, MT, at the Montana State University Red Bluff Agricultural Research Station in Norris, MT, USA (5049898.184N, 451464.866E (UTM)) at an elevation of $1600 \mathrm{~m}$. Site vegetation was dominated by the native species Ericameria nauseosa, Artemisia tridentata, and Artemisia frigida in the shrub layer, and P. spicata, Stipa comata, Lupinus argenteus, and Artemisia ludviciana in the herbaceous layer. Bromus tectorum was the most abundant nonnative species. Other non-native species included: Alyssum desertorum, Sisymbrium altissimum, and Tragopogon dubious (using nomenclature of Lesica et al. (2012)). The soils of the Red Bluff site were part of the Nuley-rock outcrop complex; sandy loam $(0-10 \mathrm{~cm})$, sandy clay loam $(10-28 \mathrm{~cm})$, gravelly sandy loam $(28-61 \mathrm{~cm})$ (http://websoilsurvey.nrcs. usda.gov/app/websoilsurvey.aspx).
Temperatures during our study were similar but warmer than the historical averages of the Norris climate station, $16 \mathrm{~km}$ south of the Red Bluff research station (Online Resource 1; NCEI 2016). Over the last 30 years (1984-2013), the coldest quarter (January-March) has averaged $0.85{ }^{\circ} \mathrm{C}$, while the warmest quarter (July-September) has averaged $19.35{ }^{\circ} \mathrm{C}$. During the same 30-year period (1984-2013), April-June have been the wettest months receiving an average of $46 \%$ of the annual precipitation, and January-March have been the driest months receiving an average of $12 \%$ of the annual precipitation (Online Resource 1; NCEI 2016).

\section{Experimental design}

The research questions were addressed using two burn treatments (burned and unburned), and three different climate treatments (control, warming, warming + drying). Given the relative importance of summer temperature in defining $B$. tectorum distribution and invasion compared to winter temperatures (Bradley 2009; Taylor 2014; Bradley et al. 2016; Brummer et al. 2016) and the climate predictions in our area that project increased summer temperatures (Mote and Salathé 2010; Pederson et al. 2010; Polley et al. 2013) our warming treatments were implemented between April and October for 3 years $(2014,2015,2016)$. At the beginning of each growing season, new $2 \mathrm{~m}^{2}$ plots were randomly located within a $30 \mathrm{~m} \times 60 \mathrm{~m}$ grid, which had a uniform slope and aspect, and natural densities of $B$. tectorum and P. spicata. The six climate-burn treatments were replicated ten times in 2014 , after which, a power test was conducted and the number of replicates was reduced to six for 2015 and 2016.

In accordance with local fire restrictions, at the beginning of each year the $2 \mathrm{~m}^{2}$ plots implemented that year were burned in early April. Consistent with prescribed burning methods (Sirois 1993; Kral et al. 2015) a propane torch was used (Red Dragon model VT21/2 vapor propane torch by Flame Engineering Corporation, La Crosse, Kansas) in conjunction with a temporary fire block created out of aluminum flashing material (Jones et al. 2015). The climate manipulation structures (see below) were established in April immediately after the burn treatment. Delmhorst soil moisture measuring systems (model KS-D1) were installed in the center of each plot at a depth of $10 \mathrm{~cm}$ (Aho and Weaver 2008) and were read regularly. Temperatures were recorded ( 3 hourly) using Maxim Integrated thermochron iButton devices (DS1921G; $-40{ }^{\circ} \mathrm{C}$ : $-85^{\circ} \mathrm{C}$ ) that were deployed in each plot on the north side of a stake $20 \mathrm{~cm}$ above the soil surface. 


\section{Climate manipulation designs}

Open top chambers. Open top chambers (OTC) were used to increase the temperature of the warming and warming + drying treatments, following the cone chamber design (Molau and Molgaard 1996; Marion et al. 1997). The OTC design was intended to increase mean temperatures by $2{ }^{\circ} \mathrm{C}$. They were constructed out of Sun-Lite HP ( $1 \mathrm{~mm}$ thick) (Solar Components Corporation, Manchester, New Hampshire) fiberglass material that has relatively high solar transmittance in the visible wavelengths $(86 \%)$ and a low transmittance in the infra-red range $(<5 \%)$. The chambers had basal diameters of $1.5 \mathrm{~m}$ and top openings with diameters of $1.0 \mathrm{~m}$. The chambers were $0.4 \mathrm{~m}$ tall with a $60^{\circ}$ incline (Marion et al. 1997).

Rainout shelters. Rainout shelters following the design specified in Yahdjian and Sala (2002) were placed over OTCs to decrease the precipitation for the warming + drying treatment by $55 \%$. They were constructed with wooden frames supporting gutters made of corrugated clear polycarbonate material (Suntuf) to remove precipitation from the plots. Suntuf clear polycarbonate was used because of its high light transmittance of $90 \%$, and its toughness and flexibility to withstand high winds and inclement weather. The gutters extended $0.10 \mathrm{~m}$ beyond the OTC on the high side and $0.20 \mathrm{~m}$ on the low side to maximize interception and to prevent capillary action of soil water from inadvertently watering the vegetation within the plot. To maximize their effectiveness, the rainout shelters were oriented southwest towards the prevailing winds.

\section{Sampling methods}

Plots were only sampled throughout the growing season in which they were implemented. To account for edge effects, sampling took place within a smaller $0.75 \mathrm{~m}^{2}$ area centered in each of the treated $2 \mathrm{~m}^{2}$ plots. Total aerial cover (\%), density of reproductive tillers, aboveground biomass, the number of seeds produced plot $^{-1}$, and individual fecundity (seeds produced stem $\left.{ }^{-1}\right)$ were assessed for both target species $(B$. tectorum and $P$. spicata). Cover was assessed visually by the same two observers, who calibrated their estimates at the beginning of each sampling day. Density of reproductive tillers was assessed at the plot level throughout the growing season. In all years, destructive sampling (clipping) of aboveground B. tectorum biomass occurred on June 30th, while $P$. spicata biomass sampling took place on July 14 th. For both species, individual fecundity was assessed on a subsample of 10 stems for each plot at seed maturity by counting all filled seeds. In addition, each year a community assessment was taken on June 30th, during which the cover was assessed for all species individually.

\section{Statistical analysis}

Temperature and soil moisture data were analyzed using linear mixed-effects models, treating plot and time (Julian day for each year) as random effects and the climate and burned treatments as fixed effects. As we were interested in plant available soil water, we constrained our analysis to soil moisture above the permanent wilting point ( -15 bars).

Linear mixed-effects models were also used to assess the effects of climate, the burned treatment, and other explanatory variables on the B. tectorum response variables (cover, aboveground biomass, reproductive tiller density, seeds produced plot $^{-1}$, and individual fecundity). The experimental treatments (climate manipulation and burn), along with native grass cover and forb cover were treated as fixed effects, while year was treated as a random effect. Initially, the relative importance of the different predictor variables (climate and burn treatments, the interaction between these two experimental treatments, forb and native grass cover) on B. tectorum's cover was assessed using the difference in Akaike Information Criterion (AIC) values. A difference of two in AIC values between models was used as the threshold indicating a better fit model. All further analysis of B. tectorum response variables compared nested models, beginning with the full model that included all explanatory variables that were fully crossed. Variables and interactions that did not explain a considerable amount of variability within the data were removed until the best and most parsimonious model that included the experimental climate and burn treatments was obtained.

Linear mixed-effects models were also used to assess the effects of the experimental treatments and B. tectorum cover on the $P$. spicata response variables (cover, aboveground biomass, reproductive tiller density, seeds produced plot $^{-1}$, and individual fecundity), and native grass cover and community diversity (Simpson's and Shannon's diversity indices). The same approach as described above was used to discern between models. Species richness data (total and native) were analyzed using generalized linear mixed-effects models with a Poisson distribution. To avoid bias, because we used $B$. tectorum cover as a predictor variable, it was excluded from all biodiversity calculations.

To satisfy assumptions of normality and constant variance, B. tectorum and P. spicata variables were naturally $\log$ transformed. These assumptions were assessed visually and using the Breusch-Pagan test. Significant differences between predictor variables and response variables at the $P<0.05$ level were calculated from T statistics based on Satterthwaite's approximations of degrees of freedom for linear mixed-effects models (Kuznetsova et al. 2014). Data were analyzed using the lme4 package (Bates et al. 2011) and the lmerTest package (Kuznetsova et al. 2014) in the 
statistical analysis program R (R Development Core team 2015).

\section{Results}

The open top chambers significantly increased the mean and maximum temperatures of the warming, and warming + drying treatments, while the warming + drying treatment also increased minimum temperatures (Table 1; Online Resources 2-4). The burned treatment did not affect temperatures. The mean soil water potential for each of the 3 years (2014, 2015, 2016) demonstrated that the rainout shelters reduced water potential in all years (Online Resources 5-7). The burned treatment did not affect soil moisture. The shelters were designed to reduce precipitation by $55 \%$. We did not quantify the exact reduction in precipitation but assessed soil moisture, as it is more directly relevant to plant growth.

Total community native grass cover was the most important variable explaining the variation in B. tectorum cover

Table 1 Average mean, minimum, and maximum temperatures within the ambient, warming, and warming + drying climate treatments recorded at Red Bluff Research Station (2014-2016) imposed from April-October

\begin{tabular}{|c|c|c|c|c|}
\hline Year & Treatment & Mean $\left({ }^{\circ} \mathrm{C}\right)$ & $\begin{array}{l}\text { Minimum } \\
\left({ }^{\circ} \mathrm{C}\right)\end{array}$ & Maximum $\left({ }^{\circ} \mathrm{C}\right)$ \\
\hline \multicolumn{5}{|l|}{ April } \\
\hline \multirow[t]{3}{*}{2015} & Ambient & $7.19^{\mathrm{a}}$ & $-2.78^{a}$ & $19.77^{\mathrm{a}}$ \\
\hline & Warming & $8.80^{\mathrm{b}}$ & $-2.77^{\mathrm{a}}$ & $24.23^{\mathrm{b}}$ \\
\hline & $\begin{array}{l}\text { Warm- } \\
\text { ing + drying }\end{array}$ & $9.10^{\mathrm{b}}$ & $-1.75^{b}$ & $23.51^{\mathrm{b}}$ \\
\hline \multirow[t]{3}{*}{2016} & Ambient & $9.24^{\mathrm{a}}$ & $1.30^{\mathrm{a}}$ & $20.76^{\mathrm{a}}$ \\
\hline & Warming & $10.70^{\mathrm{b}}$ & $1.03^{\mathrm{b}}$ & $25.34^{\mathrm{b}}$ \\
\hline & $\begin{array}{l}\text { Warm- } \\
\text { ing + drying }\end{array}$ & $11.09^{\mathrm{b}}$ & $1.66^{\mathrm{c}}$ & $24.96^{\mathrm{b}}$ \\
\hline \multicolumn{5}{|c|}{ May-July } \\
\hline \multirow[t]{3}{*}{2014} & Ambient & $17.00^{\mathrm{a}}$ & $5.86^{\mathrm{a}}$ & $29.77^{\mathrm{a}}$ \\
\hline & Warming & $18.40^{\mathrm{b}}$ & $5.85^{\mathrm{a}}$ & $34.00^{\mathrm{b}}$ \\
\hline & $\begin{array}{l}\text { Warm- } \\
\text { ing + drying }\end{array}$ & $18.68^{\mathrm{b}}$ & $6.53^{\mathrm{b}}$ & $32.57^{\mathrm{c}}$ \\
\hline \multirow[t]{3}{*}{2015} & Ambient & $18.08^{\mathrm{a}}$ & $7.76^{\mathrm{a}}$ & $31.62^{\mathrm{a}}$ \\
\hline & Warming & $19.96^{\mathrm{b}}$ & $7.80^{\mathrm{a}}$ & $36.25^{\mathrm{b}}$ \\
\hline & $\begin{array}{l}\text { Warm- } \\
\text { ing + drying }\end{array}$ & $20.15^{\mathrm{b}}$ & $8.74^{\mathrm{b}}$ & $35.05^{\mathrm{b}}$ \\
\hline \multirow[t]{3}{*}{2016} & Ambient & $18.44^{\mathrm{a}}$ & $6.64^{\mathrm{a}}$ & $32.28^{\mathrm{a}}$ \\
\hline & Warming & $20.16^{\mathrm{b}}$ & $6.31^{\mathrm{b}}$ & $37.08^{\mathrm{b}}$ \\
\hline & $\begin{array}{l}\text { Warm- } \\
\text { ing + drying }\end{array}$ & $20.58^{b}$ & $7.29^{c}$ & $36.36^{\mathrm{b}}$ \\
\hline
\end{tabular}

Data shown here represents the growing season (April-July) effects of the treatments. 2014 April temperature data were not available. Yearly data were analyzed separately and superscripts indicate statistical significance $(P<0.05)$
(\%) followed by the climate treatments, while other variables accounted for little of the variation within the data (Table 2). As such, the best cover model included both experimental treatments (climate and burn) and total native grass community cover (\%). As expected, the results of the model demonstrated a negative relationship between $B$. tectorum cover and total native grass cover $(P<0.001)$. However, contrary to our expectations, the warming treatment negatively affected $B$. tectorum cover $(P=0.035$; Table 3 ; Fig. 1). B. tectorum cover also responded negatively to the warming + drying treatment $(P=0.007$, respectively; Table 3; Fig. 1). The burned treatment did not affect $B$. tectorum cover $(P=0.105$; Table 3$)$.

Bromus tectorum aboveground biomass (g) also demonstrated a negative relationship with total native grass community cover $(P<0.001)$ and to the warming + drying treatment $(P=0.022$; Table 3$)$. Neither the warming treatment nor the burned treatment affected $B$. tectorum biomass ( $P=0.080$ and $P=0.345$, respectively; Table 3$)$. Bromus tectorum reproductive density (tiller plot $^{-1}$ ) and seed production (seeds plot $^{-1}$ ) demonstrated negative relationships with the total native grass community cover $(P<0.001$ and $P<0.001$, respectively). They were also negatively affected by both the warming $(P=0.010$ and $P=0.020$, respectively) and the warming + drying climate treatments ( $P<0.001$ and $P=0.005$, respectively; Table 3 ). However, they were not significantly affected by the burned treatment ( $P=0.065$ and $P=0.117$, respectively; Table 3 ). Individual B. tectorum fecundity (seeds stem ${ }^{-1}$ ) was not affected by either climate treatment, but responded negatively to total community native grass cover $(P=0.034)$. Interestingly, $B$. tectorum individual fecundity responded positively to the burned treatment $(P<0.001$; Fig. 2; Table 3$)$.

Table 2 Akaike Information Criterion (AIC) table testing the effects of vegetation cover and the climate and burned treatments on Bromus tectorum cover

\begin{tabular}{llcc}
\hline Model & Tested factor & AIC & $\Delta$ AIC \\
\hline •Full model & NA & 338.12 & 0 \\
•Full-forb cover & Forb cover & 336.84 & -1.28 \\
•Full-native grass cover & Native grass cover & 377.29 & 39.17 \\
*Climate + veg & Burn treatment & 337.40 & -0.72 \\
$*$ Burn + veg & Climate treatment & 341.23 & 3.11 \\
$*$ Climate + burn + veg & Climate $\times$ burn interac- & 336.54 & -1.58 \\
& tion & & \\
\hline
\end{tabular}

Delta $(\Delta)$ AIC indicates the relative importance of the tested explanatory variable (higher delta values indicate those factors that were most important)

-Full model $=\operatorname{lmer}(\ln ($ B. tectorum cover $) \sim($ climate $\mathrm{x}$ burn status) + native grass + forb $+(1$ year $)$

$*$ Veg $=$ Native grass cover + forb cover 
Table 3 Results of the best linear mixed-effects models assessing Bromus tectorum responses to the burned, warming, warming + drying treatments, and native grass cover

\begin{tabular}{|c|c|c|c|c|c|c|c|c|}
\hline \multicolumn{7}{|l|}{ Fixed effects } & \multirow{2}{*}{\multicolumn{2}{|c|}{$\begin{array}{l}\text { Random effects } \\
\text { Variance }\end{array}$}} \\
\hline \multirow[t]{2}{*}{ Response } & \multirow[t]{2}{*}{ Predictor } & \multirow[t]{2}{*}{ Est. } & \multirow[t]{2}{*}{ SE } & \multirow[t]{2}{*}{$d f$} & \multirow[t]{2}{*}{$t$ value } & \multirow[t]{2}{*}{$P(>)$} & & \\
\hline & & & & & & & Year & Residual \\
\hline \multirow[t]{5}{*}{ Cover $(\%)$} & Intercept & 3.65 & 0.43 & 4.50 & 8.54 & $<0.001$ & $0.34 \pm 0.59$ & $0.70 \pm 0.84$ \\
\hline & Burned & -0.25 & 0.15 & 120.98 & -1.63 & 0.105 & & \\
\hline & Warming & -0.39 & 0.18 & 120.99 & -2.14 & 0.035 & & \\
\hline & Warming + drying & -0.50 & 0.18 & 120.97 & -2.77 & 0.007 & & \\
\hline & Native grass cover $(\%)$ & -0.06 & 0.01 & 121.21 & -7.00 & $<0.001$ & & \\
\hline \multirow[t]{5}{*}{ Aboveground biomass (g) } & Intercept & 3.23 & 0.47 & 6.54 & 6.83 & $<0.001$ & $0.43 \pm 0.66$ & $0.82 \pm 0.90$ \\
\hline & Burned & -0.16 & 0.17 & 125.01 & -0.95 & 0.345 & & \\
\hline & Warming & -0.35 & 0.20 & 125.02 & -1.77 & 0.080 & & \\
\hline & Warming + drying & -0.45 & 0.19 & 125.00 & -2.32 & 0.022 & & \\
\hline & Native grass cover $(\%)$ & -0.05 & 0.01 & 125.23 & -5.33 & $<0.001$ & & \\
\hline \multirow[t]{5}{*}{ Reproductive density (tillers plot ${ }^{-1}$ ) } & Intercept & 6.80 & 0.60 & 7.51 & 11.54 & $<0.001$ & $0.61 \pm 0.78$ & $1.47 \pm 1.21$ \\
\hline & Burned & -0.41 & 0.22 & 124.95 & -1.86 & 0.065 & & \\
\hline & Warming & -0.69 & 0.26 & 124.97 & -2.62 & 0.010 & & \\
\hline & Warming + drying & -0.95 & 0.26 & 124.94 & -3.65 & $<0.001$ & & \\
\hline & Native grass cover $(\%)$ & -0.08 & 0.01 & 125.23 & -6.14 & $<0.001$ & & \\
\hline \multirow[t]{5}{*}{ Seed production (seeds plot $^{-1}$ ) } & Intercept & 8.21 & 0.89 & 5.58 & 9.26 & $<0.001$ & $1.67 \pm 1.29$ & $2.11 \pm 1.45$ \\
\hline & Burned & 0.43 & 0.27 & 120.00 & 1.58 & 0.117 & & \\
\hline & Warming & -0.77 & 0.32 & 120.00 & -2.36 & 0.020 & & \\
\hline & Warming + drying & -0.92 & 0.32 & 120.01 & -2.87 & 0.005 & & \\
\hline & Native grass cover $(\%)$ & -0.09 & 0.02 & 120.12 & -4.77 & $<0.001$ & & \\
\hline \multirow[t]{5}{*}{ Individual fecundity (mean seeds stem ${ }^{-1}$ ) } & Intercept & 2.02 & 0.47 & 3.88 & 4.32 & 0.013 & $0.57 \pm 0.76$ & $0.26 \pm 0.51$ \\
\hline & Burned & 0.53 & 0.09 & 120.01 & 5.62 & $<0.001$ & & \\
\hline & Warming & -0.12 & 0.11 & 120.02 & -1.08 & 0.282 & & \\
\hline & Warming + drying & -0.18 & 0.11 & 120.02 & -1.58 & 0.116 & & \\
\hline & Native grass cover $(\%)$ & -0.01 & 0.01 & 120.06 & -2.14 & 0.034 & & \\
\hline
\end{tabular}

Values in bold indicate statistically significant differences $(P<0.05)$. Response variables were assessed at the plot level $\left(0.75 \mathrm{~m}^{2}\right)$, except individual fecundity, which is mean seeds stem ${ }^{-1}$

Pseudoroegneria spicata cover (\%) (Fig. 3), aboveground biomass (g), reproductive density (tiller plot ${ }^{-1}$ ), and seed production (seeds plot $^{-1}$ ) were lower in the presence of B. tectorum ( $P=0.001, P=0.012, P=0.010, P=0.017$, respectively; Table 4). Pseudoroegneria spicata cover (Fig. 3) and biomass responded negatively to the warming + drying treatment $(P=0.010$ and $P=0.005)$. However, neither metric was affected by the warming or the burned treatments (Table 4). Both P. spicata reproductive density and seed production were negatively affected by the warming treatment $(P=0.020$ and $P=0.043$, respectively) and the warming + drying treatment $(P<0.001$ and $P<0.001$, respectively) but not the burned treatment (Table 4). Pseudoroegneria spicata individual fecundity (seeds stem ${ }^{-1}$ ) was not affected by any of the experimental treatments, or $B$. tectorum cover (Table 4 ).

Analysis of the total native grass community cover demonstrated that it was reduced in the presence of $B$. tectorum $(P<0.001)$, and negatively affected by the warming, and warming + drying climate treatments $(P=0.044$ and $P=0.045$, respectively), as well as the burned treatment $(P<0.001$; Fig. 4). Total and native species richness, as well as Simpson's and Shannon's diversity indices were negatively affected by $B$. tectorum cover $(P<0.001, P<0.001$, $P=0.030, P<0.001$, respectively). Species richness, both total and native, and the Simpson's diversity index were not affected by either climate treatment or the burned treatment. However, the warming + drying treatment negatively affected the Shannon's diversity index $(P=0.040)$. 


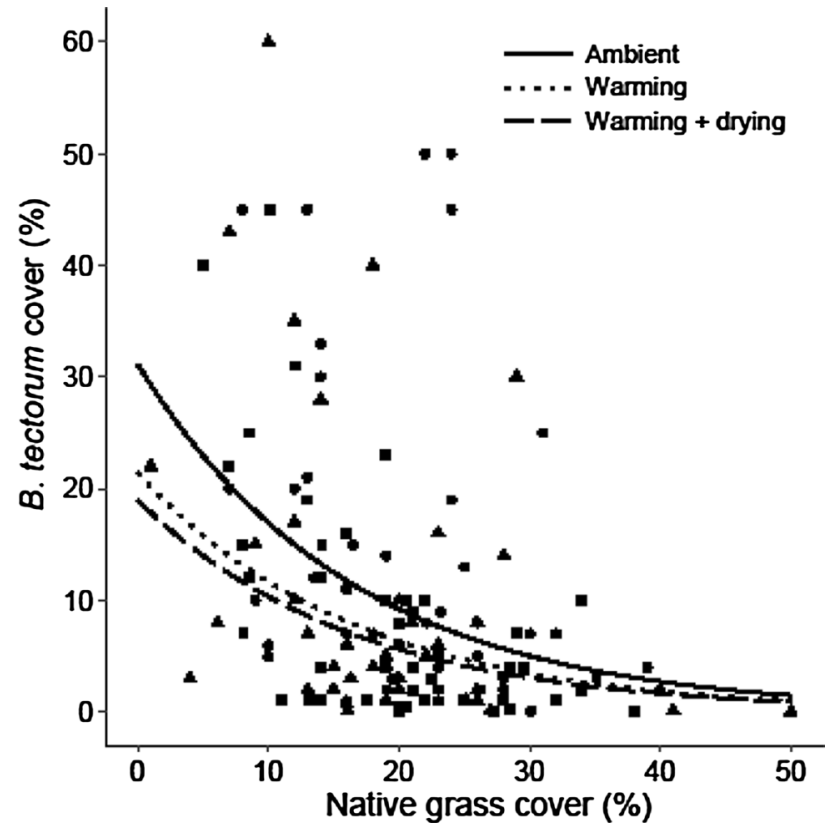

Fig. 1 Bromus tectorum cover response to native grass cover within ambient (circles, solid line), warming (triangles, dotted line), and warming + drying (squares, dashed line) climate treatment plots $\left(0.75 \mathrm{~m}^{2}\right)$. Results of a linear mixed-effects model demonstrated that $B$. tectorum cover was negatively affected by native grass cover $(n=132, P<0.001)$, warming $(n=44, P=0.035)$, and warming + drying $(n=44, P=0.007)$

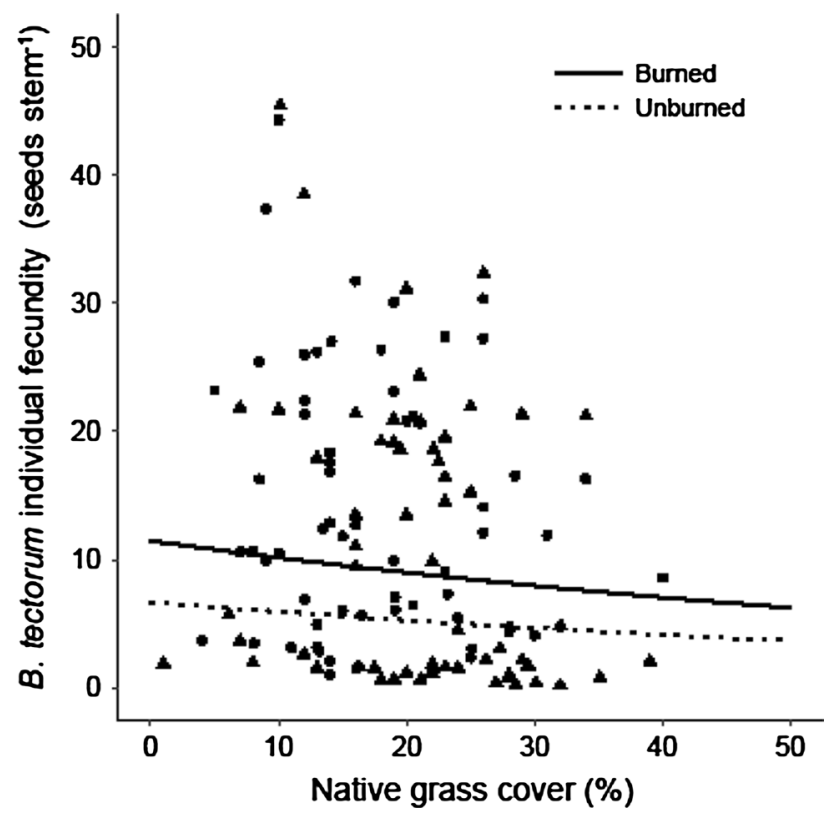

Fig. 2 Bromus tectorum individual fecundity (seeds stem ${ }^{-1}$ ) response to the native grass cover within burned (circles, solid line), and unburned (triangles, dotted line) plots $\left(0.75 \mathrm{~m}^{2}\right)$. Results of a linear mixed-effects model demonstrated that $B$. tectorum fecundity was negatively affected by native grass cover $(n=132, P=0.034)$ and positively affected by the burned treatment $(n=66, P<0.001)$

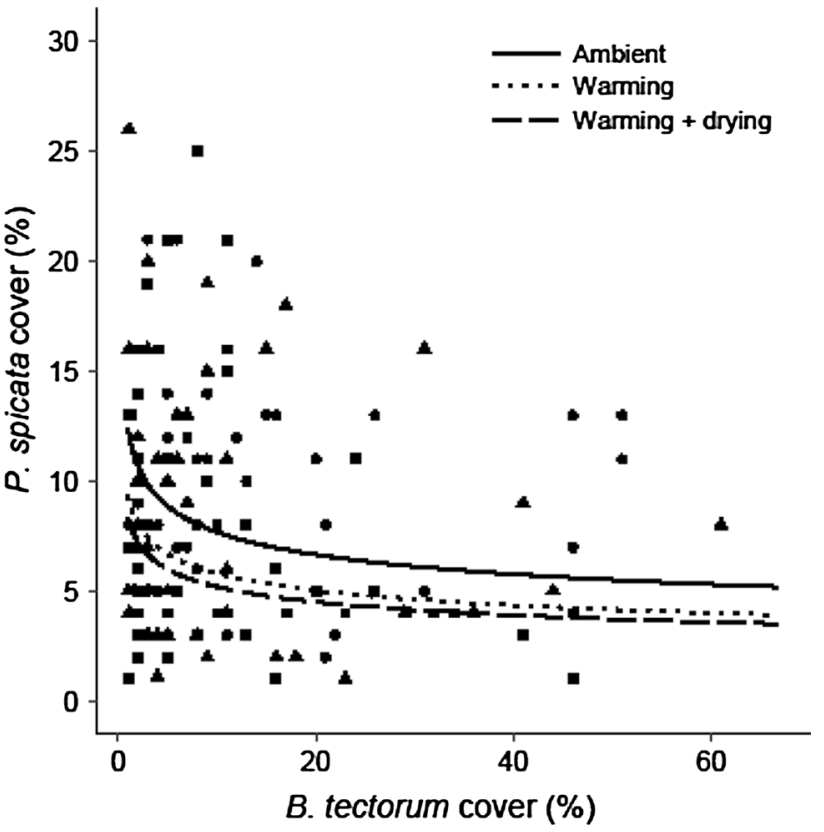

Fig. 3 Pseudoroegneria spicata cover response to B. tectorum cover within the ambient (circles, solid line), warming (triangles, dotted line), and warming + drying (squares, dashed line) climate treatment plots $\left(0.75 \mathrm{~m}^{2}\right)$. Results of a linear mixed-effects model demonstrated $P$. spicata cover was lower in the presence of B. tectorum $(n=132$, $P=0.001)$ and was negatively affected by the warming +drying climate treatment $(n=44, P=0.001)$. Pseudoroegneria spicata cover was not affected by the warming treatment $(n=44, P=0.061)$

\section{Discussion}

\section{Responses to elevated temperatures}

One of the most documented and significant ecological effects of increasing temperatures associated with global climate change is the impact it has had on species range distributions; many species range have shifted up in elevation and poleward in latitude (McCarty 2001; Walther et al. 2002; Parmesan 2006; Lenoir and Svenning 2014). A metaanalysis of studies that experimentally manipulated climate factors found that experimental warming stimulated photosynthesis and plant growth (Wu et al. 2011). Similarly, field experiments have demonstrated that when there is sufficient water available for growth $B$. tectorum has responded positively to experimentally increased temperatures (Zelikova et al. 2013; Compagnoni and Adler 2014a, b; Blumenthal et al. 2016). Therefore, contrary to our expectations, we found B. tectorum, P. spicata, and total native grass cover all responded negatively to experimental warming.

Our warming treatment $\left(+\sim 1.5^{\circ} \mathrm{C}\right)$ was similar to previous $B$. tectorum warming studies, which warmed between 1.5 and $7{ }^{\circ} \mathrm{C}$ (Zelikova et al. 2013; Compagnoni and Adler 2014a, b; Blumenthal et al. 2016). However, the majority of these studies warmed continuously throughout the winter, 
Table 4 Results of the best linear mixed-effects models assessing Pseudoroegneria spicata responses to the burned, warming, warming + drying treatments, and Bromus tectorum cover

\begin{tabular}{|c|c|c|c|c|c|c|c|c|}
\hline \multicolumn{7}{|l|}{ Fixed effects } & \multirow{2}{*}{\multicolumn{2}{|c|}{$\frac{\text { Random effects }}{\text { Variance }}$}} \\
\hline \multirow[t]{2}{*}{ Response } & \multirow[t]{2}{*}{ Predictor } & \multirow[t]{2}{*}{ Est. } & \multirow[t]{2}{*}{ SE } & \multirow[t]{2}{*}{$d f$} & \multirow[t]{2}{*}{$t$ value } & \multirow[t]{2}{*}{$P(>)$} & & \\
\hline & & & & & & & Year & Residual \\
\hline \multirow[t]{5}{*}{ Cover $(\%)$} & Intercept & 2.55 & 0.28 & 4.81 & 9.20 & $<0.001$ & $0.13 \pm 0.37$ & $0.47 \pm 0.68$ \\
\hline & Burned & -0.08 & 0.12 & 121.03 & -0.66 & 0.511 & & \\
\hline & Warming & -0.28 & 0.15 & 121.03 & -1.89 & 0.061 & & \\
\hline & Warming + drying & -0.39 & 0.15 & 121.10 & -2.61 & 0.010 & & \\
\hline & B. tectorum cover $(\%)$ & -0.21 & 0.06 & 122.96 & -3.31 & 0.001 & & \\
\hline \multirow[t]{5}{*}{ Aboveground biomass (g) } & Intercept & 1.82 & 0.40 & 2.99 & 4.57 & 0.020 & $0.38 \pm 0.61$ & $0.47 \pm 0.68$ \\
\hline & Burned & -0.14 & 0.12 & 121.04 & -1.14 & 0.256 & & \\
\hline & Warming & -0.26 & 0.15 & 121.04 & -1.71 & 0.090 & & \\
\hline & Warming + drying & -0.53 & 0.15 & 121.07 & -3.56 & 0.005 & & \\
\hline & B. tectorum cover $(\%)$ & -0.16 & 0.06 & 122.36 & -2.54 & 0.012 & & \\
\hline \multirow[t]{5}{*}{ Reproductive density (tillers plot ${ }^{-1}$ ) } & Intercept & 3.30 & 0.54 & 5.37 & 6.10 & 0.001 & $0.63 \pm 0.79$ & $1.21 \pm 1.10$ \\
\hline & Burned & -0.19 & 0.20 & 125.05 & -0.99 & 0.326 & & \\
\hline & Warming & -0.57 & 0.24 & 125.05 & -2.35 & 0.020 & & \\
\hline & Warming + drying & -1.03 & 0.24 & 125.09 & -4.30 & $<0.001$ & & \\
\hline & B. tectorum cover $(\%)$ & -0.26 & 0.10 & 127.11 & -2.60 & 0.010 & & \\
\hline \multirow[t]{5}{*}{ Seed production (seeds plot $^{-1}$ ) } & Intercept & 6.10 & 0.93 & 3.75 & 6.53 & 0.004 & $1.82 \pm 1.35$ & $3.85 \pm 1.96$ \\
\hline & Burned & 0.31 & 0.35 & 121.06 & -0.89 & 0.374 & & \\
\hline & Warming & -0.88 & 0.43 & 121.07 & -2.05 & 0.043 & & \\
\hline & Warming + drying & -1.76 & 0.43 & 121.11 & -4.12 & $<0.001$ & & \\
\hline & B. tectorum cover $(\%)$ & -0.43 & 0.18 & 122.85 & -2.41 & 0.017 & & \\
\hline \multirow[t]{5}{*}{ Individual fecundity (mean seeds stem ${ }^{-1}$ ) } & Intercept & 2.75 & 0.10 & 26.61 & 27.98 & $<0.001$ & $0.005 \pm 0.07$ & $0.11 \pm 0.33$ \\
\hline & Burned & -0.08 & 0.06 & 107.37 & -1.29 & 0.200 & & \\
\hline & Warming & -0.01 & 0.08 & 107.66 & -0.19 & 0.848 & & \\
\hline & Warming + drying & -0.09 & 0.08 & 107.52 & -1.17 & 0.244 & & \\
\hline & B. tectorum cover $(\%)$ & -0.02 & 0.03 & 91.96 & -0.67 & 0.504 & & \\
\hline
\end{tabular}

Values in bold indicate statistically significant differences $(P<0.05)$. Response variables were assessed at the plot level $\left(0.75 \mathrm{~m}^{2}\right)$, except individual fecundity, which is mean seeds stem ${ }^{-1}$

as well as during the growing season. It is unclear if warming during the winter at our site would have elicited a positive response by $B$. tectorum. Cold temperatures decrease B. tectorum germination (Roundy et al. 2007), and low soil temperatures constrain its establishment, growth, and reproduction (Chambers et al. 2007; Bradley et al. 2016). However, over-winter warming would have also resulted in a reduced snowpack, which, in previous studies at cold locations, has resulted in exposing $B$. tectorum to more extreme cold events and decreased over winter survival (Griffith and Loik 2010). In addition, a recent observational study conducted at sites with climates similar to ours (cold and dry winters, warm and wet summers) found that overall annual brome grass abundance (including $B$. tectorum) was lowest when the winter temperatures were warmer than the historical average (Ashton et al. 2016), presumably due to overwinter mortality. Therefore, the more likely explanation as to why our B. tectorum, and P. spicata, responded negatively to our warming treatments is that our site receives less late winter/early spring precipitation than studies conducted to the south, and our warming increased evapotranspiration and heightened plant water stress during the spring-summer growing season.

\section{Responses to seasonality of precipitation and soil moisture availability}

Precipitation patterns, specifically timing of precipitation, strongly influences $B$. tectorum establishment, growth, and reproduction (Bradford and Lauenroth 2006; Prevéy and Seastedt 2015; Bradley et al. 2016). Two Colorado field studies demonstrated that when winter precipitation in the form of rain was increased $B$. tectorum responded positively, and when it was reduced, $B$. tectorum responded negatively (Prevéy and Seastedt 2014, 2015). On sites that averaged 85,128 , and $122 \mathrm{~mm}$ of total precipitation between January 


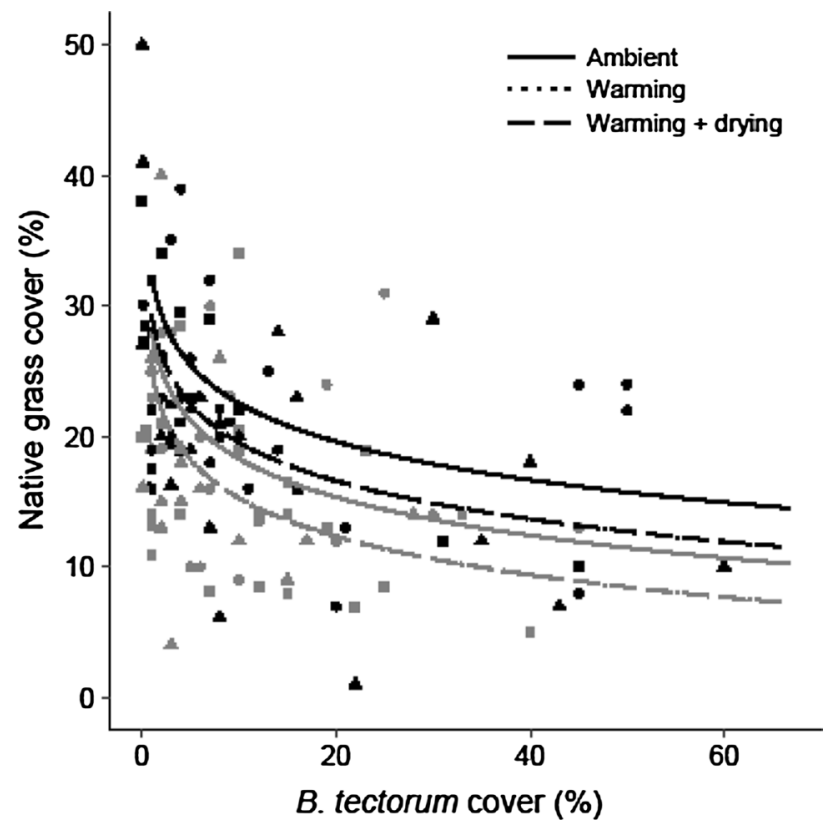

Fig. 4 Native grass cover in the ambient (circles, solid line), warming (triangles, dotted line), and warming + drying (squares, dashed line) climate treatment plots $\left(0.75 \mathrm{~m}^{2}\right)$ for unburned (black) and burned (gray) fire treatments. Results of a linear mixed-effects model demonstrated that native grass cover was lower in the presence of $B$. tectorum $(n=132, P<0.001)$ and was negatively affected by the warming and warming + drying climate treatments $(n=44$, $P=0.044,0.045$, respectively), as well as the burned treatment $(n=66, P<0.001)$. The native grass cover trend lines for both climate treatments occlude each other for the burn and unburned treatments

and March (wrcc.dri.edu/summary), Compagnoni and Adler (2014a) found B. tectorum fecundity and survival responded positively to experimentally increased temperatures. Contrasting with this, our site only received 47 and $79 \mathrm{~mm}$ of total precipitation between January and March in 2015 and 2016, respectively, which is normal for our area. In these years, the $B$. tectorum response was significantly negative. In 2014, when our site received a similar amount of January-March precipitation $(128 \mathrm{~mm})$ to the more southerly studies, B. tectorum responded neutrally to the warming treatment. This same trend was reported in another study: Zelikova et al. (2013) found that B. tectorum responded positively to experimental warming when there was ample (110 $\mathrm{mm}$ ) precipitation between January and March; however, when there was considerably less January-March precipitation $(18,25,45 \mathrm{~mm}), B$. tectorum responses were largely either negative or neutral.

Bromus tectorum establishment, survival, growth, and reproduction, in areas with limited fall/winter germination, has been found to be highly dependent on spring precipitation (Mack and Pyke 1983; Meyer et al. 2001; Bradford and Lauenroth 2006; Roundy et al. 2007; Concilio et al. 2013;
Zelikova et al. 2013). The low fall germination at our site (Authors, personal observation), in combination with its cold temperatures and relatively low winter precipitation, limits $B$. tectorum winter survival and restricts $B$. tectorum's effective growing season to April-June. This makes precipitation during this period vital for growth of $B$. tectorum. Therefore, unsurprisingly and consistent with our expectations, when we decreased precipitation during the spring-summer growing season, B. tectorum responded negatively. These results were consistent with a recent Northern Great Basin study, which found April and May precipitation to be strong drivers of $B$. tectorum and, when reduced, resulted in low $B$. tectorum cover (Boyte et al. 2016).

Reduced precipitation, observed or manipulated, within the sagebrush/cool season perennial grasslands has resulted in decreased native grass cover and abundance (Anderson and Inouye 2001; Heitschmidt et al. 2005). When precipitation was experimentally decreased in conjunction with increased temperatures, total community production (Harte and Shaw 1995) and graminoid growth (Cherwin and Knapp 2012) of two separate Colorado sagebrush steppe sites was reduced. Similarly, it has previously been shown that $P$. spicata is unable to extract water from extremely dry soils and responds negatively to drought conditions, thus it has a limited capacity to respond to the combination of reduced water and increased temperatures (Harris 1967; Cline et al. 1977; Fraser et al. 2009). Thus, it was not surprising that our warming + drying treatment negatively affected the overall cover of the native grass community and the cover and abundance of $P$. spicata.

\section{Bromus tectorum, climate, and the native grass community}

Despite the demonstrated importance of climate, native perennial grass communities are the most important factor affecting $B$. tectorum growth and landscape position (Brummer et al. 2016). Similarly, in situ manipulative climate studies have found that native perennial grass community abundance better explains $B$. tectorum abundance than either temperature (Compagnoni and Adler 2014a) or precipitation (Prevéy and Seastedt 2015). Consistent with these studies and our expectations, the native grass community had a larger suppressive effect on $B$. tectorum abundance than either climate treatment.

Bromus tectorum has responded positively to experimentally increased temperatures (Zelikova et al. 2013; Compagnoni and Adler 2014a, b; Blumenthal et al. 2016) and has a shallow diffuse root system, which allows it to maximize use of available water, making it competitive with perennial sagebrush grasses under dry spring/summer conditions (Hull 1963; Harris 1967; Link et al. 1990). In a controlled setting, Hull (1963) found that B. tectorum had higher water 
use efficiency than a common perennial competitor, needing 0.66 as much water to produce $1 \mathrm{~g}$ of dry matter. Harris (1967) reported that $B$. tectorum was more competitive for soil water with seedlings of two perennial competitors, including $P$. spicata, because of greater root growth rates during the winter. Finally, a controlled setting experiment demonstrated that warm and dry conditions enhanced $B$. tectorum's competitiveness with established $P$. spicata individuals (Larson et al. unpublished data). Furthermore, $B$. tectorum cover, as well as warm and dry climate conditions, has been associated with reduced community biodiversity and richness (Ashton et al. 2016; Bansal and Sheley 2016). Therefore, we investigated if $B$. tectorum would be more competitive with the native grass community and would have larger effects on community biodiversity in warm and dry growing season conditions. This did not occur. Pseudoroegneria spicata, the native grass community, and the community biodiversity indices demonstrated negative relationships with $B$. tectorum. However, the cold soils and the low late winter/early spring precipitation of our site did not allow for early $B$. tectorum establishment and growth. Thus, our $B$. tectorum populations did not have the established diffuse root systems needed to maximize use of available soil water, which has previously given $B$. tectorum a competitive advantage over native competitors in dry spring/summer conditions. As such, our warming and drying treatment only intensified $B$. tectorum water stress during the growing season and failed to increase its competitiveness with the native grass community and its effects on community biodiversity metrics.

\section{The effects of fire on the native grass community and Bromus tectorum}

A decrease in native grass cover the first growing season after a fire is common (Bailey and Anderson 1978; Whisenant and Uresk 1989; West and Yorks 2002; Davies et al. 2012; Reed-dustin et al. 2016). Miller et al. (2013) reported that $86 \%$ of the Great Basin fire literature demonstrated a decrease in perennial grass cover the first year after a burn. Therefore, the negative response by the native grass community to the burn treatment is both consistent with the literature and was expected. Factors affecting these responses include slope, aspect, topography, and climate (Reed-dustin et al. 2016). Studies have found that experimentally decreased precipitation and increased temperatures after a burn have decreased native community resilience, resulting in limited post-fire recovery, consistent with significant community shifts away from pre-fire conditions (Enright et al. 2014). Consistent with the literature, the native grass community cover responded to our burn treatment and was sensitive to our post-fire climate conditions. Thus, we conclude that in the first year after a fire our imposed warmer and warmer + drier conditions decreased native community resilience. While an initial negative response to fire is expected by native grass communities, they also respond quickly and are often back to pre-fire conditions within 2-3 years (Baily and Anderson 1978; West and Yorks 2002; Davies et al. 2012). Therefore, conclusions about the long-term resilience to fire of our site under warmer and warmer and drier conditions are limited.

Using experimental warming, warming + drying, and an experimental burn, we addressed the bioclimatic envelope models which have posited that, given adequate winter/ spring precipitation, increased summer temperatures and decreased summer precipitation resulting from global climate change will increase $B$. tectorum's invasiveness and may initiate the positive feedback between fire and $B$. tectorum in sagebrush ecosystems where they have previously been limited by climates with cooler mean temperatures and receive the majority of their precipitation in the summer, such as Montana (Bradley 2009; Taylor et al. 2014; Bradley et al. 2016). However, because of our site's low late winter/ early spring precipitation, the results of our experimental warming and warming + drying treatments had deleterious effects on B. tectorum growth and abundance. Furthermore, we only observed a limited positive response by $B$. tectorum to fire, which was not heightened by the experimental warming and drying. Overall, these results add to other studies showing a lack of positive fire-feedback in the cold and wet northern sagebrush biome, including Montana (Taylor et al. 2014). Despite lowered native community resilience to fire in our warming and warming + drying treatments, our short-term results provide three main findings. In the colder northern sagebrush biome that receives more summer than winter precipitation: (1) warmer and drier growing season conditions lower ecosystem resilience to disturbance; but (2) the threat of B. tectorum becoming a transformative species as the result of climate warming is low unless there is a shift in seasonal precipitation, where more winter precipitation could facilitate earlier B. tectorum establishment and growth; and (3) the effects of climate change may be modified by spring burning, which negatively impacts native grasses more than it does $B$. tectorum, potentially leading to an indirect positive impact of climate on B. tectorum.

Acknowledgements We would like to thank Noelani Boise, Chance Noffsinger and Kaylee Schmitz for their assistance with field work. Funding for this research was provided by the Montana Noxious Weed Trust Fund. LJR is supported by the National Institute of Food and Agriculture, U.S. Department of Agriculture Hatch: MONB00363.

Author contribution statement CDL, EAL and LJR conceived and designed the research. CDL collected and analyzed the data with assistance from LJR. CDL wrote the manuscript with contributions from LJR and EAL. 
Open Access This article is distributed under the terms of the Creative Commons Attribution 4.0 International License (http://creativecommons.org/licenses/by/4.0/), which permits unrestricted use, distribution, and reproduction in any medium, provided you give appropriate credit to the original author(s) and the source, provide a link to the Creative Commons license, and indicate if changes were made.

\section{References}

Aho K, Weaver T (2008) Measuring soil water potential with gypsum blocks: calibration and sensitivity. Intermt J Sci 14:51-60

Anderson JE, Inouye RS (2001) Landscape-scale changes in plant species abundance and biodiversity of a sagebrush steppe over 45 years. Ecol Monogr 71:531-556. doi:10.1890/0012-9615(2001)071[0531:LSCIPS]2.0.CO;2

Ashton IA, Symstad AJ, Davis CJ et al (2016) Preserving prairies: understanding temporal and spatial patterns of invasive annual bromes in the Northern Great Plains. Ecosphere 7:e01438. doi:10.1002/ecs2.1438

Bailey AW, Anderson ML (1978) Prescribed burning of a Festuca-Stipa grassland. J Range Manag 31:446-449. doi: $10.2307 / 3897204$

Bansal S, Sheley RL (2016) Annual grass invasion in sagebrush steppe: the relative importance of climate, soil properties and biotic interactions. Oecologia 181:543. doi:10.1007/s00442-016-3583-8

Bates D, Maechler M, Bolker B (2011) lme4: Linear mixed-effects models using S4 classes. R package version 0.999999-2. http:// lme4.r-forge.r-project.org/

Blumenthal DM, Kray JA, Ortmans W et al (2016) Cheatgrass is favored by warming but not $\mathrm{CO}_{2}$ enrichment in a semi-arid grassland. Glob Change Biol 22:3026-3038. doi:10.1111/gcb.13278

Boyte SP, Wylie BK, Major DJ (2016) Cheatgrass percent cover change: comparing recent estimates to climate change-driven predictions in the Norther Great Basin. Rangeland Ecol and Manage 69:265-279. doi:10.1016/j.rama.2016.03.002

Bradford JB, Lauenroth WK (2006) Controls over invasion of Bromus tectorum: the importance of climate, soil, and seed availability. $\mathrm{J}$ Veg Sci 17:693-704. doi:10.1658/1100-9233(2006)17[693:COI OBT]2.0.CO;2

Bradley BA (2009) Regional analysis of the impacts of climate change on cheatgrass invasion shows potential risk and opportunity. Glob Chang Biol 15:196-208. doi:10.1111/j.1365-2486.2008.01709.x

Bradley BA, Curtis CA, Chambers JC (2016) Bromus response to climate and projected changes with climate change. In: Germino MJ, Chambers JC, Brown CS (eds) Exotic Brome-grasses in arid and semiarid ecosystems of the Western US. Springer International Publishing, Cham, pp 257-274

Bromberg JE, Kumar S, Brown CS et al (2011) Distributional changes and range predictions of downy brome (Bromus tectorum) in Rocky Mountain National Park. Invasive Plant Sci Manag 4:173-182. doi:10.1614/IPSM-D-10-00022.1

Brummer TJ, Taylor KT, Rotella J et al (2016) Drivers of Bromus tectorum abundance in the western North American sagebrush steppe. Ecosystems 19:986-1000. doi:10.1007/s10021-016-9980-3

Chambers JC, Roundy BA, Blank RR et al (2007) What makes Great Basin sagebrush ecosystems invasible by Bromus tectorum? Ecol Monogr 77:117-145. doi:10.1890/05-1991

Chambers JC, Bradley BA, Brown CS et al (2014a) Resilience to stress and disturbance, and resistance to Bromus tectorum $\mathrm{L}$. invasion in cold desert shrublands of western North America. Ecosystems 17:360-375. doi:10.1007/s10021-013-9725-5

Chambers JC, Miller RF, Board DI et al (2014b) Resilience and resistance of sagebrush ecosystems: implications for state and transition models and management treatments. Rangel Ecol Manag 67:440-454. doi:10.2111/REM-D-13-00074.1

Cherwin K, Knapp A (2012) Unexpected patterns of sensitivity to drought in three semi-arid grasslands. Oecologia 169:845-852. doi:10.1007/s00442-011-2235-2

Cline JF, Uresk DW, Rickard WH (1977) Comparison of soil water used by a sagebrush-bunchgrass and a cheatgrass community. J Range Manage 30:199-201. doi:10.2307/3897469

Compagnoni A, Adler PB (2014a) Warming, competition, and Bromus tectorum population growth across an elevation gradient. Ecosphere 5(121):1-18. doi:10.1890/ES14-00047.1

Compagnoni A, Adler PB (2014b) Warming, soil moisture, and loss of snow increase Bromus tectorum's population growth rate. Elem Sci Anthr 2:1-10. doi:10.12952/journal.elementa.000020

Concilio AL, Loik ME, Belnap J (2013) Global change effects on Bromus tectorum L. (Poaceae) at its high-elevation range margin. Glob Chang Biol 19:161-172. doi:10.1111/gcb.12032

Davies KW, Bates JD, Nafus AM (2012) Comparing burned and mowed treatments in mountain big sagebrush steppe. Environ Manag 50:451-461. doi:10.1007/s00267-012-9898-2

Downs JL, Larson KB, Cullinan VI (2016) Mapping cheatgrass across the range of the greater sage grouse: linking biophysical, climate and remote sensing data to predict cheatgrass occurrence. Pacific Northwest National Laboratory, United States Fish and Wildlife Service, Richland

Enright NJ, Fontaine JB, Lamont BB et al (2014) Resistance and resilience to changing climate and fire regime depend on plant functional traits. J Ecol 102:1572-1581. doi:10.1111/1365-2745.12306

Fraser LH, Greenall A, Carlyle C et al (2009) Adaptive phenotypic plasticity of Pseudoroegneria spicata: response of stomatal density, leaf area and biomass to changes in water supply and increased temperature. Ann Bot 103:769-775. doi:10.1093/aob/ $\operatorname{men} 252$

Gilmanov TG, Svejcar TJ, Johnson DA et al (2006) Long-term dynamics of production, respiration, and net $\mathrm{CO}_{2}$ exchange in two sagebrush steppe ecosystems. Rangel Ecol Manag 59:585-599. doi:10.2111/05-198R1.1

Griffith AB, Loik ME (2010) Effects of climate and snow depth on Bromus tectorum population dynamics at high elevation. Oecologia 164:821-832. doi:10.1007/S00442-01

Harris GA (1967) Some competitive relationships between Agropyron spicatum and Bromus tectorum. Ecol Monogr 37:89-111. doi: $10.2307 / 2937337$

Harte J, Shaw R (1995) Experiment shifting dominance within a montane vegetation community: results of a climate-warming experiment. Science (80-) 267:876-880. doi:10.1126/ science.267.5199.876

Heitschmidt RK, Klement KD, Haferkamp MR (2005) Interactive effects of drought and grazing on Northern Great Plains rangelands. Rangel Ecol Manag 58:11-19. doi:10.2111/1551-5028(2005)58<11:IEODAG > 2.0.CO;2

Hellmann JJ, Byers JE, Bierwagen BG et al (2008) Five potential consequences of climate change for invasive species. Conserv Biol 22:534-543. doi:10.1111/j.1523-1739.2008.00951.x

Hull A (1963) Competition and water requirements of cheatgrass and wheatgrasses in the greenhouse. J Range Manage 16:199-204. doi: $10.2307 / 3895674$

Jones R, Chambers JC, Johnson DW et al (2015) Effect of repeated burning on plant and soil carbon and nitrogen in cheatgrass (Bromus tectorum) dominated ecosystems. Plant Soil 386:4764. doi:10.1007/s11104-014-2242-2

Knapp PA (1996) Cheatgrass (Bromus tectorum L.) dominance in the Great Basin desert. Glob Environ Chang 6:37-52. doi:10.1016/0959-3780(95)00112-3 
Kral KC, Limb RF, Hovick TJ et al (2015) Simulating grassland prescribed fires using experimental approaches. Fire Ecol 11:34-44. doi:10.4996/fireecology.1103034

Kuznetsova A, Brockhoff PB, Christensen RHB (2014) lmerTest: tests in linear mixed effects models. $\mathrm{R}$ package version 2.0-20. http://CRAN.R-project.org/package=lmerTest

Lenoir J, Svenning JC (2014) Climate-related range shifts-a global multidimensional synthesis and new research directions. Ecography 37:1-14. doi:10.1111/ecog.00967

Lesica P, Lavin M, Stickney PF (2012) Manual of Montana vascular plants. BRIT Press, Fort Worth

Link SO, Gee GW, Downs JL (1990) The effect of water stress on phenological and ecophysiological characteristics of cheatgrass and Sandberg's bluegrass. J Range Manage 43:506-513. doi: $10.2307 / 4002354$

Mack RN (1981) Invasion of Bromus tectorum L. into western North America: an ecological chronicle. Agro-Ecosyst 7:145-165. doi:10.1016/0304-3746(81)90027-5

Mack RN, Pyke DA (1983) The demography of Bromus tectorum variation in time and space. J Ecol 71:69-93. doi:10.2307/2259964

Marion G, Henry G, Freckman D et al (1997) Open-top designs for manipulating field temperature in high-latitude ecosystems. Glob Chang Biol 3:20-32. doi:10.1111/j.1365-2486.1997. gcb136.x

McCarty JP (2001) Ecological consequences of recent climate change. Conserv Biol 15:320-331. doi:10.1046/j.1523-1739.2001.015002320.x

Meyer SE, Garvin SC, Beckstead J (2001) Factors mediating cheatgrass invasion of intact salt desert shrubland. In: McArthur DE, Fairbanks DJ (eds) Shrubland ecosystem genetics and biodiversity: proceedings. Proceedings of RMRS-P-21. Ogden, UT: U.S. Department of Agriculture, Forest Service, Rocky Mountain Research Station, pp 224-232

Miller RF, Knick ST, Pyke DA et al (2011) Characteristics of sagebrush habitats and limitations to long-term conservation. In: Knick ST, Connelly JW (eds) Greater Sage-Grouse: ecology and conservation of a landscape species and its habitats. University of California Press, Berkeley, pp 145-184

Miller RF, Chambers JC, Pyke DA et al (2013) Fire effects on vegetation and soils in the Great Basin: response and site characteristics. Gen. Tech. Rep. RMRS-GTR-308. US Department of Agriculture, Forest Service, Rocky Mountain Research Station, Fort Collins, CO, USA

Molau U, Molgaard P (1996) International tundra experiment (ITEX) manual. Danish Polar Center, Copenhagen

Morrow LA, Stahlman PW (1984) The history and distribution of downy brome (Bromus tectorum) in North America. Weed Sci 32:2-6. doi:10.1017/S0043174500060173

Mote PW, Salathé EP (2010) Future climate in the Pacific Northwest. Clim Change 102:29-50. doi:10.1007/s10584-010-9848-z

National Centers for Environmental Information (2016) Global summary of the month (1908-2016), Norris MT. United States Department of Commerce, National Oceanic \& Atmospheric Administration. http://ncdc.noaa.gov/cdo-web/datasets

Parmesan C (2006) Ecological and evolutionary responses to recent climate change. Annu Rev Ecol Evol Syst 37:637-669. doi:10.1146/ annurev.ecolsys.37.091305.110100

Pederson GT, Graumlich LJ, Fagre DB et al (2010) A century of climate and ecosystem change in western Montana: What do temperature trends portend? Clim Change 98:133-154. doi:10.1007/ s10584-009-9642-y

Polley HW, Briske DD, Morgan JA et al (2013) Climate change and North American rangelands: trends, projections, and implications. Rangel Ecol Manag 66:493-511. doi:10.2111/REM-D-12-00068.1

Prevéy JS, Seastedt TR (2014) Seasonality of precipitation interacts with exotic species to alter composition and phenology of a semi-arid grassland. J Ecol 102:1549-1561. doi:10.1111/1365-2745.12320

Prevéy JS, Seastedt TR (2015) Effects of precipitation change and neighboring plants on population dynamics of Bromus tectorum. Oecologia 179:765-775. doi:10.1007/s00442-015-3398-Z

R Development Core Team (2015) R: a language and environment for statistical computing, 3.2.2 edn. R Foundation for Statistical Computing, Vienna, Austria

Reed-dustin ACM, Mata-gonzález R, Rodhouse TJ (2016) Long-term fire effects on native and invasive grasses in protected area sagebrush steppe. Rangel Ecol Manag 69:257-264. doi:10.1016/j. rama.2016.03.001

Richardson DM, Pyšek P, Rejmánek M et al (2000) Naturalization and invasion of alien plants: concepts and definitions. Div Distrib 6:93-107. doi:10.1046/j.1472-4642.2000.00083.x

Roundy BA, Hardegree SP, Chambers JC et al (2007) Prediction of cheatgrass field germination potential using wet thermal accumulation. Rangel Ecol Manag 60:613-623. doi:10.2111/05-206R3.1

Rowland MM, Suring LH, Wisdom MJ, et al. (2010). Assessment of habitat threats to shrublands in the Great Basin: a case study. In: Pye J, Rauscher H, Sands Y, Lee D, Beatty J (eds) Advances in threat assessment and their application to forest and rangeland management. PNW-GTR-802. USDA Forest Service, Pacific Northwest and Southern Research Stations, Portland, Oregon, USA, pp 673-685

Sirois L (1993) Impact of fire on Picea mariana and Pinus banksiana seedlings in subarctic lichen. J Veg Sci 4:795-802. doi: $10.2307 / 3235617$

Suring LH, Wisdom MJ, Tausch RJ (2005) Modeling threats to sagebrush and other shrubland communities. In: Wisdom MJ, Rowland MM, Suring LH (eds) Habitat threats in the sagebrush ecosystem: methods of regional assessment and applications in the Great Basin. Alliance Communications Group, Allen Press, Lawrence, pp. 114-119

Suring LH, Wisdom MJ, Tausch RJ (2005b) Modeling threats to sagebrush and other shrubland communities. In: Wisdom MJ, Rowland MM, Suring LH (eds) Habitat threats in the sagebrush ecosystem: methods of regional assessment and applications in the Great Basin. Alliance Communications Group, Allen Press, Lawrence, pp 114-119

Soil Survey Staff, Natural Resources Conservation Service, United States Department of Agriculture. Web Soil Survey. http://websoilsurvey.nrcs.gov/

Taylor K, Brummer T, Rew LJ et al (2014) Bromus tectorum response to fire varies with climate conditions. Ecosystems 17:960-973. doi:10.1007/s10021-014-9771-7

Walther GR, Post E, Convey P et al (2002) Ecological responses to recent climate change. Nature 416:389-395. doi:10.1038/416389a

West NE, Yorks TP (2002) Vegetation responses following wildfire on grazed and ungrazed sagebrush semi-desert. J Range Manage 55:171-181. doi:10.2307/4003353

Whisenant SG, Uresk DW (1989) Burning upland, mixed prairie in Badlands National Park. Prairie Nat 21:221-227

Wu Z, Dijkstra P, Koch GW et al (2011) Responses of terrestrial ecosystems to temperature and precipitation change: a meta-analysis of experimental manipulation. Glob Chang Biol 17:927-942. doi:10.1111/j.1365-2486.2010.02302.x

Yahdjian L, Sala O (2002) A rainout shelter design for intercepting different amounts of rainfall. Oecologia 133:95-101. doi:10.1007/ s00442-002-1024-3

Zelikova TJ, Hufbauer RA, Reed SC et al (2013) Eco-evolutionary responses of Bromus tectorum to climate change: implications for biological invasions. Ecol Evol 3:1374-1387. doi:10.1002/ ece 3.542 